\title{
CYANYLATION OF THE SINGLE SULFHYDRYL GROUP IN CARBOXYPEPTIDASE Y WITH CYANOGEN BROMIDE
}

by

\author{
KLAUS BREDDAM and ANDERS KANSTRUP
}

Department of Chemistry, Carlsberg Laboratory, Gamle Carlsberg Vej 10, DK-2500 Copenhagen Valby

\begin{abstract}
Keywords: Carboxypeptidase, serine carboxypeptidase, chemical modification, cyanogen bromide, cyanylation
\end{abstract}

\begin{abstract}
The unblocked cysteinyl residue ( $\mathrm{Cys}^{341}$ ), located at the binding site of carboxypeptidase $Y$, does not react with the bulky cyanylating reagent 2-nitro-5-thiocyanatobenzoic acid unless the enzyme is denatured. However, it reacts specifically with small concentrations of ${ }^{14} \mathrm{CNBr}$ forming the corresponding alkyl thiocyanate. This results in reductions in the $\mathrm{k}_{\mathrm{ca}} / \mathrm{K}_{\mathrm{m}}$ values for the hydrolysis of ester and peptide substrates to $5-25 \%$ of the values obtained with unmodified enzyme, due both to decreases in the $k_{c a t}$ values and increases in the $K_{m}$ values. The rate of deacylation of the indoleacryloyl acyl enzyme intermediate, formed by reaction of the cyanylated enzyme with indoleacryloyl imidazole, is reduced to $20 \%$ of the value obtained with the unmodified enzyme. The results suggest that $\mathrm{Cys}^{341}$ participates in catalysis although it is not essential.
\end{abstract}

\section{INTRODUCTION}

A number of carboxypeptidases and endopeptidases belonging to the serine family are inhibited by alkyl mercurials due to modification of a single sulfhydryl group $(2,3,4,13,15,17)$. In the case of carboxypeptidase $\mathrm{Y}$ from yeast (CPD-Y) it has been shown that the extent of inhibition is dependent on the bulkiness of both the reagent and the amino acid residue occupying the $P_{1}$ position of the substrate $(2,4)$. These results indicate that the cysteinyl residue $\left(\mathrm{Cys}^{341}\right)$ is not essential to catalysis but merely occupies a position in the $S_{1}$ binding site of the enzyme. It would be desirable to confirm this conclusion by attaching other types and in particular less bulky groups to this cysteinyl residue. Unfortunately, it does not react with reagents like iodoacetamide, iodoacetic acid, ethyleneimine, fluorodinitrobenzene, DTNB and NTCB (5) which normally react with thiols. However, in a single case it has been reported that the inclusion of $3.3 \mathrm{M}$-urea in the reaction medium renders the

Abbreviations: $\mathrm{Bz}=$ benzoyl $\mathrm{CN}-\mathrm{CPD}-\mathrm{Y}=\mathrm{CPD}-\mathrm{Y}$ modified with cyanogen bromide; $\mathrm{CPD}-\mathrm{Y}=$ carboxypeptidase Y; DTNB = 5,5'-dithiobis(2-nitrobenzoic acid); EDTA = ethylene diamine tetraacetic acid; FA = furylacryloyl; IAI $=$ indoleacryloyl imidazole; Mes $=2$-(N-morpholino)ethane sulfonic acid; NTCB $=2$-nitro-5-thiocyanatobenzoic acid. Other abbreviations of amino acids, and peptides are according to the guidelines of the IUPAC-IUB Commission on Biochemical Nomenclature. The binding site notation is that of SCHECHTER and BERGER (22). Accordingly, the binding site for the $\mathrm{C}$-terminal residue of the substrate is denoted $\mathbf{S}_{1}^{\prime}$ and those of the amino acid residues in the $\mathrm{N}$-terminal direction away from the scissile bond are denoted $\mathrm{S}_{1}, \mathrm{~S}_{2}, \ldots, \mathrm{S}_{\mathrm{i}}$. Amino acid residues in the substrate are referred to as $P_{1}, P_{2}, \ldots, P_{i}$ in correspondence with the binding site. 
-SH group accessible to NTCB, partially converting it to an -SCN group (19). This cyanylation represents only a slight increase in bulkiness of the group occupying position 341 and it is therefore ideally suited to study the significance of the - $\mathrm{SH}$ group. In the present paper it is shown that this cyanylation can be achieved with cyanogen bromide without denaturation of the enzyme. It is further shown that the -SH group may be involved in catalysis although it is not essential.

\section{MATERIALS AND METHODS}

\subsection{Materials}

${ }^{14} \mathrm{CNBr}$ was synthesized in the following way: $500 \mu \mathrm{l}$ water and $150 \mu \mathrm{Br}_{2}$ (2.85 mmoles) was added to a $2 \mathrm{ml}$ round bottomed flask containing a magnetic stirrer. The flask was cooled to 0 ${ }^{\circ} \mathrm{C}$ and the content of the $\mathrm{K}^{14} \mathrm{CN}$ ampule (1 mg and $1 \mathrm{mCi}$ ), dissolved in $150 \mu \mathrm{l}$ water, was added to the reaction mixture. Residual $\mathrm{K}^{14} \mathrm{CN}$ was washed out with another $150 \mu \mathrm{l}$ water and added to the reaction mixture. $195 \mathrm{mg}$ unlabelled $\mathrm{KCN}$ ( 3 mmoles) was dissolved in $1 \mathrm{ml}$ water and 100 $\mu l$ portions were added with $10 \mathrm{~min}$ intervals. After 8 additions the residual $200 \mu \mathrm{l}$ was diluted with $500 \mu \mathrm{l}$ water and the additions continued until the colour of the bromine had disappeared. Stirring was then continued for another $30 \mathrm{~min}$. It is important that $\mathrm{KCN}$ is not added in excess since this results in the formation of $(\mathrm{CN})_{2}$. The

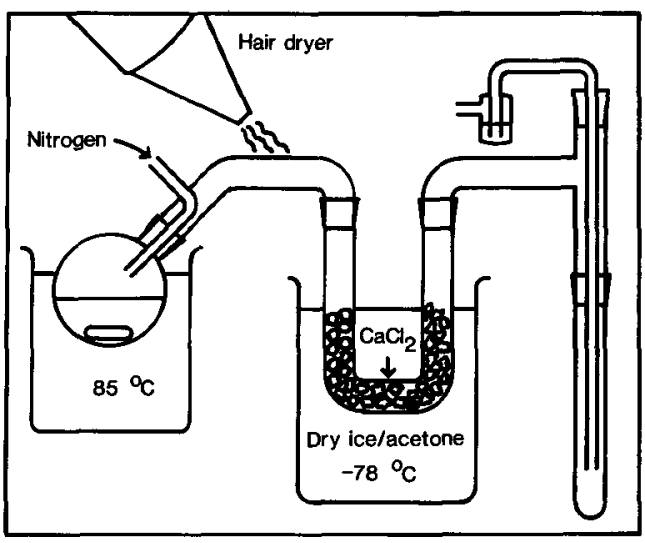

Figure 1. Setup for distillation of ${ }^{14} \mathrm{CNBr}$. reaction flask was then connected to the distillation equipment shown in Figure 1 . After $10 \mathrm{~min}$ distillation in the presence of a slow stream of dry nitrogen the reaction flask was displaced with an empty flask and a hairdryer was used to aide residual material away from the connecting tube. The cooling bath was then transferred to the flask at the right (see Figure 1), and the oilbath was transferred to the U-tube. A hairdryer was again employed to assist the transfer of cyanogen bromide into the freezing trap where it formed long white needles in the bottom. The yield was $180 \mathrm{mg}(60 \%)$ and the specific activity $0.44 \mathrm{mCi} / \mathrm{mmol}$.

Indoleacryloyl imidazole was prepared in the following manner: $1 \mathrm{~g}$ indoleacrylic acid (5.3 mmoles) was suspended in $50 \mathrm{ml}$ methylene chloride $+10 \mathrm{ml}$ acetonitrile. $400 \mathrm{mg}$ imidazole (5.9 mmoles) and $92 \mathrm{mg}$ p-toluene sulfonic acid ( 0.53 mmoles) was then added and the solution cooled to below $-5{ }^{\circ} \mathrm{C}$. $2.94 \mathrm{~g} \mathrm{~N}$-cyclohexylN'-(2-morpholinoethyl)-carbodiimid-methyl-ptoluene sulfonate $(6.9 \mathrm{mmol})$ was dissolved in 15 $\mathrm{ml}$ dry methylene chloride and added to the reaction mixture. The reaction flask was sealed and stirred for 16 hours. After evaporation of the solvent the precipitate was dissolved in $20 \mathrm{ml}$ methanol/methylene chloride (1:9) and applied to an $\mathrm{Si}_{60}$-column $(1.5 \times 70 \mathrm{~cm})$. The column was eluted with the same solvent and fractions containing the indoleacryloyl imidazole were collected and evaporated essentially to dryness at $25{ }^{\circ} \mathrm{C}$. After addition of $100 \mathrm{ml}$ benzene and evaporation to remove residual methanol the product was dissolved in a minimum of hot acetone and crystallized by dropwise addition of one volume of petroleum ether. $800 \mathrm{mg}$ yellow crystals were obtained, corresponding to a yield of $64 \%$. Melting point $188-190^{\circ} \mathrm{C}$.

The substrates FA-Phe-Leu-OH, FA-Phe-Phe$\mathrm{OH}, \mathrm{FA}-\mathrm{Ala}-\mathrm{Phe}-\mathrm{OH}$, FA-Phe-Gly-OH, and FAPhe-OEt and the reagent NTCB were synthesized as previously described $(5,8,9)$.

Carboxypeptidase $\mathrm{Y}$ was a product of Carlsberg Biotechnology, Denmark, FA-Phe-OMe was obtained from Bachem, Switzerland, cyanogen bromide from Fluka, Switzerland and all the reagents for synthesis of indoleacryloyl imidazole were from Aldrich. $\mathrm{K}^{14} \mathrm{CN}$ was purchased from Amersham, England. Hepes and 
Mes were from Sigma, USA. The $\mathrm{Si}_{60}$ resin and all other reagents were from Merck, W. Germany.

\subsection{Methods}

\subsubsection{Modifications of CPD-Y}

Treatment with NTCB was accomplished as previously described (19): $1 \mathrm{ml} 30 \mu \mathrm{M}-\mathrm{CPD}-\mathrm{Y}$ in $50 \mathrm{~mm}$ potassium phosphate, $\mathrm{pH} 7.6$ was treated with $5 \mu \mathrm{l} 25 \mathrm{~mm}-\mathrm{NTCB}$ dissolved in $50 \mathrm{~mm}$ potassium phosphate $\mathrm{pH}$ 6.9. The reaction was also performed with $3.3 \mathrm{M}$ and with $6 \mathrm{M}$-urea included in the reaction mixture. The reaction was monitored at $412 \mathrm{~nm}$, using a Cary 219 spectrophotometer. The contribution from spontaneous hydrolysis of NTCB was subtracted by addition of NTCB to $1 \mathrm{ml} 50 \mathrm{~mm}$ potassium phosphate, $\mathrm{pH} 7.6$, inserted into the reference position of the spectrophotometer. The quantitative estimation of the modification was based on $\Delta \varepsilon_{412}=13600(9)$.

Modification with cyanogen bromide was performed in the following manner: To $4 \mathrm{ml}$ CPD-Y $(7.5 \mathrm{mg} / \mathrm{ml}=120 \mu \mathrm{M})$ in $0.05 \mathrm{M}$ $\mathrm{NaH}_{2} \mathrm{PO}_{4}, \mathrm{pH} 7.5$ was added $20 \mu \mathrm{l} 22 \mathrm{mM}-\mathrm{CNBr}$ in water, corresponding to 0.92 equivalent. The activities of the enzyme were followed (see section 2.2.3) and when only small changes with time were observed, additional reagent was added until a total of $100 \mu 22 \mathrm{~mm}-\mathrm{CNBr}$. Aliquots of the reaction mixture $(500 \mu \mathrm{l})$ were taken before each addition of $\mathrm{CNBr}$ and the reaction was terminated by separating enzyme from reagent by gelfiltration on a Biogel P-4 column, equilibrated with water. The bed volume was $20-30$ fold the volume of the sample applied. The modified enzyme was stored frozen in water at $-18^{\circ} \mathrm{C}$.

\subsubsection{Characterization of modified CPD-Y}

The preparations of modified enzyme obtained after gelfiltration were analysed for amino acid composition, carbohydrate content, incorporation of radioactively labelled reagent and sulfhydryl content. The amino acid composition was determined, after acid hydrolysis for 24 hours in vacuo, using a Durrum D 500 amino acid analyser. The content of unreacted cysteine was determined by titration with para-hydroxymercuribenzoate in the absence of denaturing agents as previously described (20) or with Ellmans reagent (DTNB) under denaturing conditions: $800 \mu \mathrm{l} 6 \mathrm{M}$-guanidine hydrochloride, 0.2 M-Tris, 10 mM-EDTA, pH 8.0 was mixed with $200 \mu$ l enzyme solution (in water). The same mixture with water replacing enzyme solution served as reference. After 2 minutes incubation $10 \mu 110 \mathrm{~mm}$ ellmans reagent in methanol was added and the increase in absorbance at $412 \mathrm{~nm}$ recorded. $A \Delta \varepsilon_{412}$ of 13600 was used (11).

${ }^{14} \mathrm{C}$-measurements were performed by liquid scintillation using an LKB scintillation counter. The stoichiometry of incorporated reagent was based on spectrophotometrically determined enzyme concentrations using $A_{280}=14.8$ for a $1 \%$ solution (16). The carbohydrate content was determined by the phenol-sulphuric acid method (10). Cleavage of the modified enzyme with cyanogen bromide and chromatography on Biogel P-60 was performed as previously described (6).

\subsubsection{Determinations of enzyme activity and kinetic constants}

Assays for peptidase and esterase activities were performed at $25{ }^{\circ} \mathrm{C}$ in $0.05 \mathrm{M}$-Mes, 1 mM-EDTA, pH 6.5 and $0.05 \mathrm{M}$-Hepes, $1 \mathrm{~mm}$ EDTA, pH 7.5, respectively. Routine assay mixtures consisted of $965 \mu \mathrm{l}$ buffer, $25 \mu \mathrm{l} 8 \mathrm{mM}$ FA-Phe-Leu-OH or FA-Phe-OMe dissolved in methanol, and $10 \mu \mathrm{l}$ enzyme added directly or after an appropriate dilution in water. The kinetic constants for the hydrolysis of various FApeptide and ester substrates by CN-CPD-Y were determined from Lineweaver-Burk plots. Hydrolysis rates were determined spectrophotometrically at $329-358 \mathrm{~nm}$ using a Cary 219.

\subsubsection{Reaction of CPD-Y with $I A I$}

The reaction of CPD-Y with IAI was performed as described by MARTIN et al. (19): To $1 \mathrm{ml}$ $20 \mu \mathrm{M}-\mathrm{CPD}-\mathrm{Y}$ in $0.1 \mathrm{M}-\mathrm{KH}_{2} \mathrm{PO}_{4}, \mathrm{pH} 7.5$, equilibrated at $25^{\circ} \mathrm{C}$, was added $4 \mu \mathrm{l} 5.2 \mathrm{mM}$-IAI in acetonitrile. The spectrum between 300 and 400 $\mathrm{nm}$ was recorded with time, using a Cary 219 spectrophotometer and the rate of deacylation 
was determined from the decrease in absorbance at $355 \mathrm{~nm}$.

\section{RESULTS AND DISCUSSION}

In a previous report (19) it was demonstrated that cyanylation of the - $\mathrm{SH}$ groups of $\mathrm{Cys}^{341}$ in CPD-Y with NTCB at $\mathrm{pH} 7.6$ requires the addition of denaturing agents like urea. This result was confirmed: no cyanylation took place in phosphate buffer at $\mathrm{pH} 7.6$, but 0.3 equivalent was cyanylated within 3 hours in $3.3 \mathrm{M}$-urea and 0.8 equivalents within 2 hours in $6 \mathrm{M}$-urea (Figure 2A). The stability of CPD-Y under these reaction conditions was investigated by assay of the activity towards FA-Phe-OMe at $\mathrm{pH} 7.6$ (Figure 2B). It is seen that the enzyme was stable in the absence of urea but lost activity with time in the presence of urea: at 3 hours $40 \%$ activity was lost in $3.3 \mathrm{M}$-urea and at 2 hours $93 \%$ was lost in $6 \mathrm{M}$-urea. This approximately correlates with the extent of cyanylation and thus, it is probable that denaturation of the enzyme is a condition for reaction of $\mathrm{Cys}^{341}$ with NTCB in contrast to the claims of the previous report (19).

The inaccessibility of the -SH group to the bulky NTCB warranted an investigation of its reactivity towards less bulky reagents. Cyanylation of thiols with cyanogen bromide has been described $(1,12,18)$, but not in proteins. CPD-Y was initially treated with $0.5 \mathrm{~mm}$-cyanogen bromide at $\mathrm{pH}$ values ranging from 5.5 to 7.5 . At $\mathrm{pH}$ 5.5 cyanogen bromide had only a slight influence on the activities of the enzyme, but at $\mathrm{pH} 6.5$ and 7.5 the peptidase activity towards FA-PheLeu-OH and esterase activity towards FA-PheOMe decreased to $40 \%$ and $10 \%$ of the control, respectively, and then remained constant. The rate of the reaction was the highest at $\mathrm{pH} 7.5$ where half the esterase activity was lost within 8 minutes. The reaction was consequently studied further at this $\mathrm{pH}$ : the consecutive addition of four smaller aliquots of cyanogen bromide (see Figure $3 \mathrm{~A}$ ), each corresponding to 0.92 equivalent, also reduced the peptidase and esterase activities to $40 \%$ and $10 \%$, respectively, and an additional equivalent of reagent had no further effects. The amino acid and carbohydrate analysis of the enzyme obtained after the final addition of cyanogen bromide were identical to those

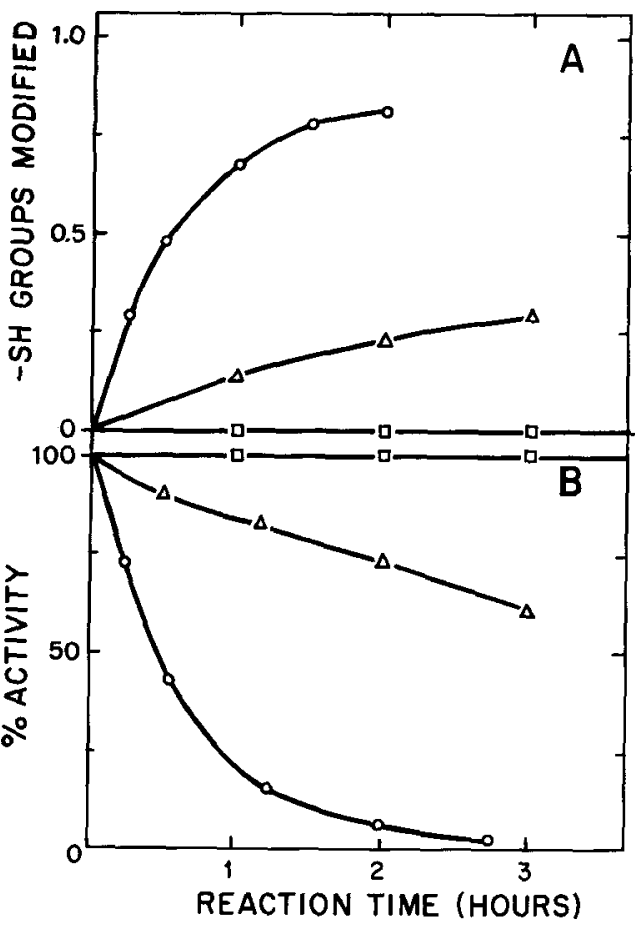

Figure 2. Panel A. Reaction of CPD-Y with NTCB in $0.1 \mathrm{M}-\mathrm{K}_{2} \mathrm{HPO}_{4}$, pH 7.6 (- $\left.\square-\square-\right), 0.1 \mathrm{M}-\mathrm{K}_{2} \mathrm{HPO}_{4}, 3.3$ M-urea, pH $7.6(-\Delta-\Delta-), 0.1 \mathrm{M}-\mathrm{K}_{2} \mathrm{HPO}_{4}, 6 \mathrm{M}$-urea, $\mathrm{pH}$ 7.6 (-O-O-). The ordinate indicates the number of cysteinyl groups modified per enzyme molecule. The reaction conditions are listed in section 2.2.1. Panel B. Stability of CPD-Y under the conditions listed in Panel A. At the times indicated the activity of the enzyme towards FA-Phe-OMe was determined and calculated as \% of the control. The assay mixture consisted of 965 $\mu 10.1 \mathrm{M}-\mathrm{K}_{2} \mathrm{HPO}_{4}$, pH $7.6+25 \mu \mathrm{l}, 8 \mathrm{~mm}-\mathrm{FA}-\mathrm{Phe}-\mathrm{OMe}$ in methanol $+10 \mu \mathrm{l}$ enzyme from the reaction mixtures of Panel A, diluted 1:21 in water.

of unmodified CPD-Y. However, the single sulfhydryl group, as determined by Ellmans reagent and p-hydroxy-mercuribenzoate had disappeared. Analysis of the sulfhydryl content of the enzyme preparations obtained at the reaction times shown by an arrow in Figure $3 \mathrm{~A}$ indicated that the loss of $90 \%$ of the esterase activity correlated with the loss of the single sulfhydryl group (Figure 3B).

The stoichiometri of the reaction of CPD-Y with cyanogen bromide was ascertained by the use of ${ }^{14} \mathrm{CNBr}$ in the way described in Figure 3. 


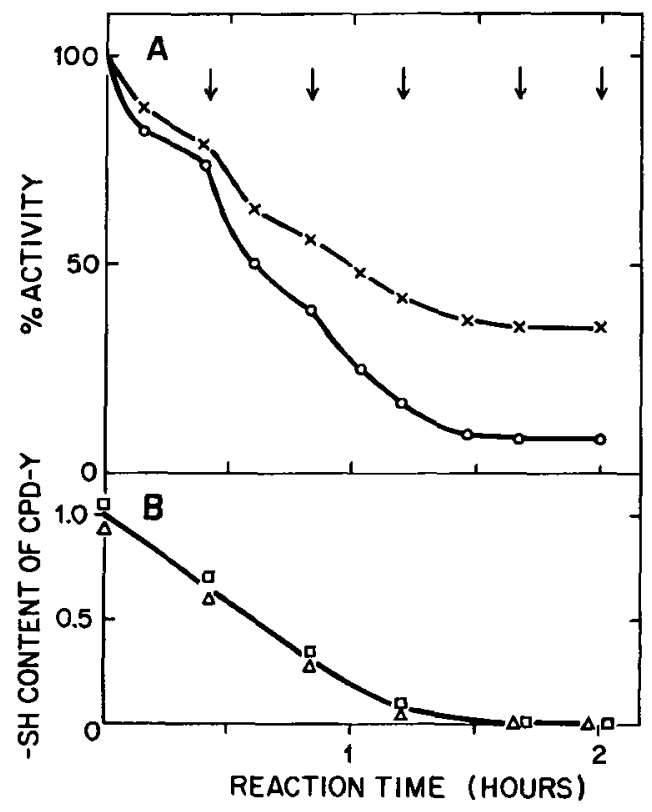

Figure 3. Modification of CPD-Y with CNBr. Panel A. Initial reaction conditions: $0.12 \mathrm{~mm}-\mathrm{CPD}-\mathrm{Y}, 0.05$ $\mathrm{M}-\mathrm{NaH}_{2} \mathrm{PO}_{4}, 0.11 \mathrm{~mm}-\mathrm{CNBr}$, pH 7.5. At the times indicated by an arrow a $500 \mu \mathrm{l}$ aliquot of the reaction mixture was desalted and then an aliquot $\mathrm{CNBr}$ was added corresponding to a $0.11 \mathrm{mM}$ raise in its concentration. During the reaction the activities towards FA-Phe-OMe (-O-O-) and FA-Phe-Leu-OH (-x-x-) were assayed (see section 2.2.3). Panel B. The content of sulfhydryl groups of the enzyme preparations obtained by desalting $0.5 \mathrm{ml}$ aliquots at times indicated by an arrow in Panel $A$ as determined by Ellman's reagent $(\square)$ and p-hydroxymercuri-benzoate $(\Delta)$.

The radioactivity measurement of the enzyme obtained at 2 hours, after the addition of five equivalents of reagent, showed that 1.2 equivalent of $\mathrm{CN}$ had been incorporated into the enzyme. Cyanogen bromide cleavage of this preparation of enzyme and subsequent gel filtration chromatography according to a previously published procedure (6) showed that $85 \%$ of the radioactivity, corresponding to 1.0 equivalent, had been incorporated into the fragment $\mathrm{Lys}^{314}$ $\mathrm{Met}^{398}$, consistent with $\mathrm{Cys}^{341}$ being the site of reaction of cyanogen bromide. Methionyl residues appear not to react at neutral $\mathrm{pH}$ at the low concentrations of $\mathrm{CNBr}$ employed, and no cleavage of the protein was observed. Cyanogen bromide may therefore be used in chemical modification studies for the specific modification of cysteinyl residues, and in particular in cases where these are inaccessible to the more commonly utilized bulky reagents like NTCB (see above). Since peptide chains specifically may be cleaved at the position of cyanylated cysteinyl residues at basic pH values $(9,14,21)$ this provides another application of $\mathrm{CNBr}$ in amino acid sequence determinations in addition to its use for cleavage at methionyl residues at acidic $\mathrm{pH}$ values.

The kinetic parameters for the hydrolysis of the ester substrates FA-Phe-OMe and FA-Phe$\mathrm{OEt}$ and the peptide substrates FA-Phe-Gly-OH, FA-Phe-Leu-OH, FA-Phe-Phe-OH, and FA-AlaPhe-OH by CN-CPD-Y were determined and compared with those previously reported for unmodified CPD-Y (5) (Table I). In the case of FA-Phe-OMe and FA-Phe-Gly-OH only $\mathrm{k}_{\text {cal }} / \mathrm{K}_{\mathrm{m}}$ is reported due to the $K_{m}$ values greatly exceeding the solubility of these substrates, thus preventing the determination of $\mathrm{k}_{\mathrm{cat}}$ and $\mathrm{K}_{\mathrm{m}}$. It is seen that CN-CPD-Y hydrolyses the other substrates with up to five fold increased $K_{m}$ values and with $k_{\text {cat }}$ values $30-45 \%$ of the values obtained with unmodified CPD-Y. Since in hydrolysis of peptides acylation is rate-limiting, i.e. $\mathrm{k}_{2} \ll \mathrm{k}_{3}$, and consequently, $\mathrm{k}_{\text {cat }} \sim \mathrm{k}_{2}$ and $\mathrm{K}_{\mathrm{m}} \sim$ $K_{s}(7)$ (see Scheme 1), the increased $K_{m}$ values for the hydrolysis of peptide substrates by $\mathrm{CN}$ CPD-Y indicate that cyanylation of $\mathrm{Cys}^{341}$ has an adverse effect on the binding of such substrates. This is consistent with $\mathrm{Cys}^{341}$ being located at the binding site of the enzyme as previous reports have indicated $(2,4)$. However, whereas introduction of e.g. the bulky phenylmercuri group at position 341 was sufficient to significantly affect the specificity of the enzyme with respect to the $P_{1}$ position of the substrate (4) this was not the case with the non-bulky cyano group: $\mathrm{k}_{\text {cat }} / \mathrm{K}_{\mathrm{m}}$ for the hydrolysis of FA-Ala-Phe$\mathrm{OH}$ and FA-Phe-Phe-OH was reduced to $25 \%$ and $15 \%$, respectively, and thus only slightly dependent on the size of the $P_{1}$ residue of the substrate.

The decreased values of $\mathrm{k}_{\text {cat }}$ for the hydrolysis of peptides indicates that the acylation reaction is adversely affected by the cyanylation of $\mathrm{Cys}^{34 !}$. However, the effects on the rate of the deacyla- 
Table I. Kinetic parameters for the hydrolysis of ester and peptide substrates by CPD-Y and CN-CPD-Y.

\begin{tabular}{|c|c|c|c|c|}
\hline & & $\begin{array}{l}k_{\mathrm{cal}} \\
\left(\mathrm{min}^{-1}\right)\end{array}$ & $\begin{array}{l}\mathrm{K}_{\mathrm{m}} \\
\mathrm{mM})\end{array}$ & $\begin{array}{l}\mathrm{k}_{\mathrm{ca}} / \mathrm{K}_{\mathrm{m}} \\
\left(\mathrm{min}^{-1} \cdot \mathrm{mM}^{-1}\right)\end{array}$ \\
\hline & CPD-Y & 11000 & 0.39 & 28000 \\
\hline \multirow[t]{2}{*}{ FA-Phe-OMe } & CN-CPD-Y & - & - & 2600 \\
\hline & CPD-Y & 11000 & 0.059 & 190000 \\
\hline \multirow[t]{2}{*}{ FA-Phe-OEt } & $\mathrm{CN}-\mathrm{CPD}-\mathrm{Y}$ & 3400 & 0.31 & 11000 \\
\hline & CPD-Y & 5800 & 5.4 & 1100 \\
\hline \multirow[t]{2}{*}{ FA-Phe-Gly-OH } & CN-CPD-Y & - & - & 200 \\
\hline & CPD-Y & 4900 & 0.021 & 230000 \\
\hline \multirow[t]{2}{*}{ FA-Phe-Leu-OH } & CN-CPD-Y & 1900 & 0.048 & 40000 \\
\hline & CPD-Y & 6200 & 0.12 & 52000 \\
\hline \multirow[t]{2}{*}{ FA-Phe-Phe-OH } & CN-CPD-Y & 2900 & 0.34 & 8500 \\
\hline & CPD-Y & 16000 & 1.2 & 13000 \\
\hline FA-Ala-Phe-OH & CN-CPD-Y & 5100 & 1.5 & 3400 \\
\hline
\end{tabular}

The rates of hydrolysis were determined spectrophotometrically at $329-358 \mathrm{~nm}$ and $25^{\circ} \mathrm{C}$. Assays were performed in $0.05 \mathrm{M}$-Hepes, $1 \mathrm{mM}$-EDTA, $2.5 \%$ methanol, pH 7.5 for ester substrates and in $0.05 \mathrm{M}-\mathrm{Mes}, 1 \mathrm{mM}-\mathrm{EDTA}, \mathrm{pH}$ 6.5 for peptide substrates.

tion reaction cannot be decided from the data in Table I: although deacylation is rate-limiting in ester hydrolysis by the serine endopeptidases and hence, $\mathbf{k}_{\mathrm{cat}} \sim \mathbf{k k}_{3}$, this is not necessarily the case with the serine carboxypeptidases (7). To

$$
\begin{aligned}
& E+S \stackrel{\mathrm{K}_{s}}{\longrightarrow} E S \stackrel{\mathrm{K}_{2}}{\longrightarrow} E S^{\prime} \stackrel{\mathrm{K}_{3}}{\longrightarrow} E+\mathrm{P}_{2} \\
& + \\
& k_{\text {cat }}=\frac{k_{2} \cdot k_{3}}{k_{2}+k_{3}} \quad k_{m}=k_{s} \cdot \frac{k_{3}}{k_{2}+k_{3}}
\end{aligned}
$$

Scheme 1: Reaction mechanism for the serine proteases. $E=$ enzyme; $S=$ substrate; $E S=$ Michaelis complex; $\mathrm{K}_{\mathrm{s}}=$ dissociation constant of the ES complex; $\mathrm{ES}^{\prime}=$ the acyl-enzyme intermediate; $P_{1}=$ leaving group; $P_{2}=$ hydrolysis product; $k_{2}$ and $k_{3}$ are the rate constants for the acylation and deacylation reactions, respectively. evaluate the influence of cyanylation of $\mathrm{Cys}^{341}$ on the deacylation process $\mathrm{CPD}-\mathrm{Y}$ and $\mathrm{CN}$ CPD-Y were reacted with 0.9 equivalent of the active site reagent IAI according to the procedure of MARTIN et al. (19). The deacylation of the resulting indoleacryloyl-acyl-enzyme intermediates of CPD-Y and CN-CPD-Y both obeyed first order kinetics with $\mathrm{k}_{3}$ values at $\mathrm{pH} 7.5$ of $10 \cdot 10^{4} \mathrm{sec}^{-1}$ and $2 \cdot 10^{4} \mathrm{sec}^{-1}$, respectively. Since cyanylation of $\mathrm{Cys}^{341}$ reduces the rates of both acylation and deacylation reactions, it is possibly involved in catalysis in a manner beyond that of substrate binding.

\section{ACKNOWLEDGEMENTS}

Professors Martin OtTEsen and Ole BUCHARDT are gratefully acknowledged for their support of the work and for carefully reading the manuscript. 


\section{REFERENCES}

1. Abramovitch, B.: Organic thiocyanates. U.S. Patent 2.486.090 (1949). Chem. Abstr. 44, 2018 (1950)

2. BAI, Y. \& R. HaYashi: Properties of the single sulfhydryl group of carboxypeptidase $Y$. Effects of alkyl and aromatic mercurials on activities toward various synthetic substrates. J. Biol. Chem. 254, 8473-8479 (1979)

3. Baudys, M., V. Kostka, G. Hausdorf, S. FittKau \& W. E. HÖHNE: Amino acid sequence of the tryptic SH-peptide of thermitase, a thermostable serine proteinase from thermoactinomyces vulgaris. Int. J. Peptide Res. 22, 66-72, (1983)

4. BREDDAM, K: Modification of the single sulfhydryl group of carboxypeptidase $Y$ with mercurials. Influence on enzyme specificity. Carlsberg Res. Commun. 48, 9-19 (1983)

5. BREDDAM, K. Modification of amino acid residues in the $S_{1}$ binding site of carboxypeptidase $Y$. Carlsberg Res. Commun. 49, 627-638 (1984)

6. BREDDAM, K. \& I. SVENDSEN: Identification of methionyl and cysteinyl residues in the substrate binding site of carboxypeptidase Y. Carlsberg Res. Commun. 49, 636-646 (1984)

7. BREDDAM, K. Serine carboxypeptidases, A review. Carlsberg Res. Commun. 51, 83-128 (1986)

8. Degani, Y.\&A.PATChornik: Selective cyanylation of sulfhydryl groups. II. On the synthesis of 2-nitro5-thiocyanatobenzoic acid. J. Org. Chem. 36, 2727-2728 (1971)

9. Degani, Y. \& A. Patchornik: Cyanylation of sulfhydryl groups by 2-nitro-5-thiocyanobenzoic acid, High-yield modification and cleavage of peptides of cysteine residues. Biochemistry 13, 1-11 (1974)

10. Dubois, M., K A. Gilles, J. K. Hamilton, P. A. REBERS \& F.SMITH: Colorimetric method for determination of sugar and related substances. Anal Chem. 38, 350-356 (1956)

11. Ellman, G. L.: Tissue sulfhydryl groups. Arch. Biochem. Biophys. 82, 70-77 (1959)
12. GUY, R. G.: The chemistry of cyanates and their thio derivatives. Part II. Ed. Patai, Wiley, N. Y., p. 857 (1977)

13. Hofmann, T.: Penicillocarboxypeptidases $S-1$ and S-2. In: Methods Enzymol., L. Lorand, ed., Academic Press, XLV pp. 587-599 (1976)

14. JacobSEN, G. R., M. H. SchafFER, G. R. StaRK \& T. C. VANAMAN: Specific chemical cleavage in high yield at the amino peptide bonds of cysteine and cystine residues. J. Biol. Chem. 248, 6583-6591 (1973)

15. JANY, K.-D., G. LeDERER \& B. MAYER: Amino acid sequence of proteinase $K$ from the mold Tritirachium album Limber. Proteinase K - a subtilisin-related enzyme with disulfide bonds. FEBS Lett. 199, 139-146 (1986)

16. JoHANSEN, J. T., K. BRedDdAM \& M. OTtESEN: Isolation of carboxypeptidase $\mathrm{Y}$ by affinity chromatography. Carlsberg Res. Commun. 41, 1-14 (1976)

17. Kominami, E., H. Hoffschulte \& H. Holzer: Purification and properties of proteinase $B$ from yeast. Biochem. Biophys. Acta 661, 124-135 (1981)

18. KoSEL, C.: Thiocyanate esters. German Patent 1.270.553(1968). Chem. Abstr. 69, 96212 u (1968)

19. Martin, B. M., R. W. A. Oliver, J. T. Johansen \& T. Viswanatha: The carboxypeptidase Y catalyzed hydrolysis of indoleacryloylimidazole. Carlsberg Res. Commun. 45, 69-78 (1980)

20. Riordan, J. F. \& B. L. VALleE: Reactions with N-ethylmaleimide and p-mercuribenzoate. Meth. Enzymol 25, 449-456 (1952)

21. SChaffer, M. H. \& G. R. STARK: Ring cleavage at 2-iminothiazolidine-4-carboxylates by catalytic reduction. A potential method for unblocking peptides formed by specific chemical cleavage at half-cystine residues. Biochem. Biophys. Res. Commun. 71, 1041-1047 (1976)

22. SCHECHTER, I. \& B. BERGER: On the size of the active site of proteases. I. Papain. Biochem. Biophys. Res. Commun. 27, 157-162 (1967) 